\title{
Growth and Micronutrients Contents of Smell Pepper (Capsicum chinense Jac.) Submitted to Organic Fertilizer
}

\author{
Sávia P. da Silva ${ }^{1}$, Ismael de J. M. Viégas ${ }^{2}$, Ricardo S. Okumura ${ }^{2}$, Dioclea A. S. Silva ${ }^{2}$, Jessivaldo R. Galvão ${ }^{1}$, \\ Mário L. da Silva Júnior ${ }^{1}$, Fábio R. R. de Araújo $^{3}$, Willian Y. W. de L. Mera ${ }^{2}$ \& Alasse O. da Silva ${ }^{2}$ \\ ${ }^{1}$ Federal Rural University of Amazônia, Belém, Brazil \\ ${ }^{2}$ Federal Rural University of Amazônia, Capanema, Brazil \\ ${ }^{3}$ Federal University of Southern and Southeastern Pará, Marabá, Brazil \\ Correspondence: Sávia Poliana da Silva, Federal Rural University of Amazônia, Belém, Pará, Brazil. Tel: \\ 55-94-99161-2021. E-mail: saviapoliana@yahoo.com.br
}

$\begin{array}{lc}\text { Received: July 31, } 2018 & \text { Accepted: September 1,2018 Online Published: October 15, } 2018 \\ \text { doi:10.5539/jas.v10n11p425 } & \text { URL: https://doi.org/10.5539/jas.v10n11p425 }\end{array}$

The research is financed by National Council for Scientific and Technological Development-CNPq, and Coordination of Improvement of Higher Education Personnel—CAPES.

\begin{abstract}
The results of research with smell pepper cultivation are still incomplete and preliminary, especially regarding organic fertilizing and nutritional status. The aims of study were to evaluate the effect of rates of organic fertilizer produced from family agriculture waste on growth and nutritional status of smell pepper. An experiment was conducted in a greenhouse at the Universidade Federal Rural da Amazônia, in Belém city, State of Pará, in period from January to April 2012. The experimental design was completely randomized, with five treatments and four replications, in which each experimental plot being made of a vase with a volume of $3.6 \mathrm{dm}^{3}$ of soil and a smell pepper seedling. Five rates of organic fertilizer $(0 \%, 15 \%, 30 \%, 45 \%$, and $60 \%)$ were tested out of the total volume of substrate. The organic fertilizer were formed by mixing chicken manure $(10 \%)$, duck manure $(20 \%)$, cassava peel $(15 \%)$, cassava leaf $(15 \%)$, bean straw $(15 \%)$, rice husk $(15 \%)$, and corn cob $(10 \%)$. The different amounts of organic fertilizer were mixed in volumetric proportions of substrate of Yellow Latosol, sandy texture, taken from the surface layer $(0-20 \mathrm{~cm})$. It was founded that at 103 days, the best results were achieved with a rate of $60 \%$ of the organic fertilizer. The content and accumulation of micronutrients in leaf tissue of smell pepper plants followed this descending order: $\mathrm{Fe}>\mathrm{B}>\mathrm{Mn}>\mathrm{Zn}>\mathrm{Cu}$, and $\mathrm{Fe}>\mathrm{B}>\mathrm{Mn}>\mathrm{Zn}>$ $\mathrm{Cu}$, respectively. In fruits, the content, accumulation, and extraction of micronutrients followed this order: $\mathrm{Fe}>$ $\mathrm{B}>\mathrm{Mn}>\mathrm{Zn}>\mathrm{Cu}$.
\end{abstract}

Keywords: mineral nutrition, sustainability, nutrient uptake

\section{Introduction}

The peppers cultivation occurs in all regions of Brazil, being one of main crops of family agriculture and small-farmer-agro-industry integration. The region of greatest genetic diversity is in Amazon, in which indigenous peoples were responsible for domestication of the species (Reifschneider, 2000). Fonseca, Lopes, Willian, Lopes, and Ferreira (2008) identified a large variation of classes in fruit traits: nine colors, four shapes and a wide variety of variation in fruit size and weight.

Currently, there has been an increase in smell pepper (Capsicum chinense Jac.) production for use as a condiment in cooking and industrialized food products, making a profitable agricultural activity, including for small canned food industries (Domenico, Coutinho, Godoy, \& Melo, 2012). In addition, the pepper shows medicinal properties, acts as a healing, antioxidant, bactericidal, helps in dissolving blood clots, prevents atherosclerosis, controls cholesterol, prevents bleeding, increases caloric expenditure and influences the release of endorphins (Paula, Reis, Ferreira, Menezes, \& Paula, 2010).

Smell pepper culture is little studied in Brazil, especially with respect to organic fertilization. In general, the fertilization recommendations are same amounts recommended for bell pepper (Capsicum annuиm L.), since are 
similar among the crops (Pinto, Lima, Salgado, \& Caliman, 2006), thus, use of organic fertilizers, can be an important alternative for pepper nutrition (Oliveira et al., 2014).

The organic production system is an efficient alternative the conservation of soil and environment and has been used by small and medium farmers, aiming not only to obtain profit, but also to ensure the sustainability in use of agricultural soils, allowing less dependence on agricultural products (Pimentel, De-Polli, \& Lana, 2009). In Pará state, there is a considerable amount of organic waste, such as cattle manure, chicken manure, annual crop residues, and wood and cassava industries, showing the importance of organic fertilization, or even association with mineral fertilization, as an alternative for agricultural producers in Amazon region.

Although smell pepper (Capsicum chinense Jac.) is easily found in northern Brazil, there is little availability of scientific information on crop and none on micronutrients requirements. Malavolta, Malavolta, Cabral and Carvalho (1991) verified that micronutrients requirements in chilli pepper (Capsicum frutescens) were $\mathrm{Fe}>\mathrm{B}>$ $\mathrm{Mn}>\mathrm{Zn}>\mathrm{Cu}$, highlight the relatively high value of boron.

Chemical composition and accumulation of nutrients in leaves and fruits are essential information to know the nutritional requirements (Viégas, Sousa, Silva, Carvalho, \& Lima, 2013), being used to estimate the amount of nutrients to be supplied to plants through fertilization (Laviola \& Dias, 2008). Thus, the aims of study were to evaluate the effect of rates of organic fertilizer produced from family agriculture waste on growth and nutritional status of smell pepper.

\section{Material and Methods}

\subsection{Experimental Site}

The experiment was conducted from January to April 2012, in a greenhouse, at Federal Rural University of Amazonia in Belém city, Pará state, Brazil, located at geographical coordinates $01^{\circ} 26^{\prime} 00^{\prime \prime} \mathrm{S}$ and $48^{\circ} 26^{\prime} 00^{\prime \prime} \mathrm{W}$. The climate according to classification of Köeppen is Af2 type, equatorial regions rainy, hot and humid, with average annual rainfall between 2500 to $3000 \mathrm{~mm}$, practically without dry periods or with a maximum of one to two months. The average annual temperature varies from 27 to $30^{\circ} \mathrm{C}$, with small oscillations of 1 to $3{ }^{\circ} \mathrm{C}$ during the year. Inside the greenhouse the temperature ranged from 26 to $35^{\circ} \mathrm{C}$. The luminous intensity inside and outside the greenhouse during the experiment period was of 321 and 694 lux, respectively, measured with digital luximeter (Instrutherm, model LD-206).

\subsection{Soil Sampling and Analysis}

The quantities of organic fertilizers were mixed in volumetric proportions with the soil classified as Yellow Latosol (Embrapa, 2013), sandy texture, collected in arable layer $(0-20 \mathrm{~cm})$ an area of secondary vegetation, in Moju city, Pará State, Brazil, for chemical and physical characterization of soil.

For determinations of clay, silt and, sand-size fractions was used pipette method. The extractors used in chemical analysis of soil samples were: $\mathrm{P}, \mathrm{Na}, \mathrm{K}, \mathrm{Fe}, \mathrm{Zn}, \mathrm{Mn}$, and $\mathrm{Cu}$ (Mehlich 1); $\mathrm{Ca}, \mathrm{Mg}$, and $\mathrm{Al}\left(\mathrm{KCl} 1 \mathrm{~mol} \mathrm{~L}^{-1}\right) ; \mathrm{H}+\mathrm{Al}$ $\left(0.5 \mathrm{~mol} \mathrm{~L}^{-1}\right.$ calcium acetate, $\mathrm{pH}$ 7.0); B (hot water); $\mathrm{S}$ (monocalcium phosphate). Organic carbon (OC) was determined by Walkley-Black method, following the methodology described by Donagema, Campos, Calderano, Teixeira and Viana (2011).

The results of physical and chemical analyzes of soil were: physical properties $\left(481 \mathrm{~g} \mathrm{~kg}^{-1}\right.$ of coarse sand, $336 \mathrm{~g}$ $\mathrm{kg}^{-1}$ of fine sand, $103 \mathrm{~g} \mathrm{~kg}^{-1}$ of silt, and $80 \mathrm{~g} \mathrm{~kg}^{-1}$ of clay); and chemical properties $\left(\mathrm{pH}_{\mathrm{H} 2 \mathrm{O}}=6.2 ; \mathrm{N}=0.13 \% ; \mathrm{P}=\right.$ $1 \mathrm{mg} \mathrm{dm}{ }^{-3} ; \mathrm{K}^{+}=0.11 \mathrm{cmol}_{\mathrm{c}} \mathrm{dm}^{-3} ; \mathrm{Na}^{+}=0.08 \mathrm{cmol}_{\mathrm{c}} \mathrm{dm}^{-3} ; \mathrm{Ca}^{2+}=2.7 \mathrm{cmol}_{\mathrm{c}} \mathrm{dm}^{-3} ; \mathrm{Mg}^{2+}=0.9 \mathrm{cmol}_{\mathrm{c}} \mathrm{dm}^{-3} ; \mathrm{S}=4.8$ $\mathrm{cmol}_{\mathrm{c}} \mathrm{dm}^{-3} ; \mathrm{Al}^{3+}=0 \mathrm{cmol}_{\mathrm{c}} \mathrm{dm}^{-3} ; \mathrm{Zn}=1.50 \mathrm{mg} \mathrm{dm}{ }^{-3} ; \mathrm{Fe}=34.6 \mathrm{mg} \mathrm{dm}^{-3} ; \mathrm{Mn}=16.8 \mathrm{mg} \mathrm{dm}^{-3} ; \mathrm{B}=0.39 \mathrm{mg} \mathrm{dm}^{-3} ;$ $\mathrm{Cu}=2.0 \mathrm{mg} \mathrm{dm}{ }^{-3} ; \mathrm{H}+\mathrm{Al}=2.6 \mathrm{cmol}_{\mathrm{c}} \mathrm{dm}^{-3} ; \mathrm{SB}=3.79 \mathrm{cmol}_{\mathrm{c}} \mathrm{dm}^{-3} ; \mathrm{CEC}_{\text {effective }}=3.79 \mathrm{cmol}_{\mathrm{c}} \mathrm{dm}^{-3} ; \mathrm{CEC}_{\mathrm{pH} 7.0}=$ $6.39 \mathrm{cmol}_{\mathrm{c}} \mathrm{dm}^{-3} ; \% \mathrm{~V}=59.31 \%$; organic matter $=23.0 \mathrm{~g} \mathrm{~kg}^{-1}$ ).

Chemical properties of organic waste showed $\mathrm{pH}=6.94 ; \mathrm{N}=15.2 \mathrm{~g} \mathrm{~kg}^{-1} ; \mathrm{C}=109.7 \mathrm{~g} \mathrm{~kg}^{-1}$; Humidity at $65^{\circ} \mathrm{C}=$ $41.69 \%$, and more information is shown in Table 1 . 
Table 1. Analysis of the organic waste at 130 days of composting

\begin{tabular}{|c|c|c|c|c|c|c|}
\hline Organic waste & $\mathrm{N}$ & $\mathrm{P}$ & $\mathrm{K}$ & $\mathrm{Ca}$ & $\mathrm{Mg}$ & $\mathrm{S}$ \\
\hline & \multicolumn{6}{|c|}{ 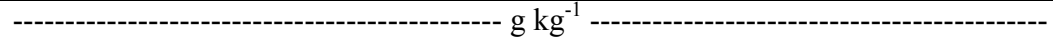 } \\
\hline Organic fertilizer & 9.1 & 12.6 & 6.3 & 52.1 & 3.6 & 7.2 \\
\hline Duck manure & 20.8 & 19.0 & 10.9 & 51.2 & 7.0 & 10.2 \\
\hline Chicken manure & 27.3 & 21.4 & 27.9 & 43.5 & 8.2 & 11.7 \\
\hline Cassava peel & 10.3 & 0.6 & 7.3 & 5.0 & 0.9 & 2.3 \\
\hline Cassava leaf & 36.6 & 2.0 & 12.2 & 12.0 & 4.4 & 15.3 \\
\hline Bean straw & 13.4 & 1.0 & 12.8 & 4.2 & 4.7 & 2.6 \\
\hline Rice husk & 6.4 & 1.5 & 4.6 & 2.7 & 0.8 & 2.3 \\
\hline Corn cob & 7.4 & 0.3 & 3.4 & 0.5 & 0.5 & 1.5 \\
\hline \multirow[t]{2}{*}{ Organic waste } & $\mathrm{Zn}$ & $\mathrm{Fe}$ & $\mathrm{Mn}$ & $\mathrm{Cu}$ & $\mathrm{B}$ & \\
\hline & \multicolumn{6}{|c|}{ |------------------------------------ mg kg ${ }^{-1}$------------------------------------ } \\
\hline Organic fertilizer & 164.0 & 2546.0 & 139.0 & 241.0 & 19.3 & \\
\hline Duck manure & 295.0 & 4012.0 & 340.5 & 42.3 & 39.2 & \\
\hline Chicken manure & 607.0 & 15457.0 & 684.0 & 297.1 & 20.9 & \\
\hline Cassava peel & 22.8 & 4639.5 & 82.6 & 8.8 & 30.8 & \\
\hline Cassava leaf & 61.5 & 120.8 & 52.8 & 6.5 & 52.6 & \\
\hline Bean straw & 20.0 & 313.3 & 42.0 & 5.1 & 61.8 & \\
\hline Rice husk & 34.9 & 6209.0 & 145.7 & 9.7 & 14.2 & \\
\hline Corn cob & 40.4 & 189.1 & 19.9 & 2.4 & 19.5 & \\
\hline
\end{tabular}

For formation of organic fertilizer was used a mixture of compounds containing high levels of carbon and nitrogen (Zhu, 2007). C is a source of energy or basic structural unit of organic molecules, thus promoting microbial growth and $\mathrm{N}$ represents a very important role in the composition of some essential elements for the growth and functioning of cells such as proteins, nucleic acids, amino acids, enzymes and coenzymes (Costa, Ximenes, Ximenes, \& Beltrame, 2015).

The organic fertilizer were formed by mixing chicken manure (10\%), duck manure (20\%), cassava peel (15\%), cassava leaf $(15 \%)$, bean straw (15\%), rice husk (15\%), and corn cob $(10 \%)$, composting process was carried out during 130 days.

\subsection{Conducting the Experiment}

Each experimental plot was consisted of one pot $\left(3.6 \mathrm{dm}^{3}\right)$ containing 1 plant of smell pepper. Soil moisture was maintained between $60 \%$ and $80 \%$ of total soil porosity, using demineralized water, and the control was done by pot weighing.

\subsection{Determination of Growth and Production Parameters}

At 103 days after sowing, vegetative growth assessments were performed: plant height $(\mathrm{cm})$, number of leaves, stem diameter $(\mathrm{mm})$, fresh and dry matter $(\mathrm{g})$, number of fruits, fresh and dried fruit matter $(\mathrm{g})$, and fruit production $(\mathrm{g})$.

To determine the plant height was used a graduated ruler from base to apex of plant, and stem diameter was obtained using a digital caliper (Alhrout, 2017). The fresh and dry matter of smell pepper was obtained by sum of stem, leaves, and roots. To obtain the dry matter were placed separately (stem, leaves, and roots) in papper bags and sent to a dried in an oven with forced air circulation at $60^{\circ} \mathrm{C}$, until reaching a constant mass (Sá et al., 2017). After, the dried samples were ground in a Wiley mill (20-mesh size).

\subsection{Laboratory Analysis of Plant Material}

After the mill processing, the samples were submitted to Laboratory of Mineral Nutrition of Plants (Universidade Federal de Viçosa) to determine the micronutrient contents (B, $\mathrm{Cu}, \mathrm{Fe}, \mathrm{Mn}$, and $\mathrm{Zn}$ ) in leaves and fruits of smell pepper (Malavolta, 2006).

For determination of $\mathrm{Fe}, \mathrm{Mn}, \mathrm{Zn}$, and $\mathrm{Cu}$ contents, the dry and ground vegetable material was submitted to nitroperchloric digestion, and quantified by atomic absorption spectrophotometry. B was analyzed after dry digestion (calcination in muffle at $550{ }^{\circ} \mathrm{C}$ ) and determined by colorimetry using Azometrine-H method.

The micronutrients accumulation $\left(\mu \mathrm{g}\right.$ leaf ${ }^{-1}$, and $\mu \mathrm{g}$ fruit ${ }^{-1}$ ) was calculated by equation:

$$
\text { Accumulation }=\left[\text { Dry Matter }(\mathrm{mg}) \times \text { Nutrient Content }\left(\mathrm{mg} \mathrm{kg}^{-1}\right)\right] / 1000
$$




\subsection{Experimental Design and Statistical Analysis}

Experimental design was a completely randomized design, with five treatments, consisting of rates of organic fertilizer in proportions of $0 \%, 15 \%(525 \mathrm{~g}), 30 \%(1050 \mathrm{~g}), 45 \%(1575 \mathrm{~g})$, and $60 \%(2100 \mathrm{~g})$ of substrate volume (Oliveira, Teixeira, \& Germano, 2004), with four replicates.

The experimental results were submitted to analysis of variance ( $F$ test, $p<0.05$ ), adjusting regression models for rates of organic fertilizer using Assistat software (Silva \& Azevedo, 2016).

\section{Results and Discussion}

\subsection{Biometric and Production Characteristics}

The experimental results obtained in present study showed a better adjustment of quadratic equation for plant height, stem diameter, number of leaves (Figure 1), and adjustment of linear equation for fresh plant weight, plant dry weight ( Figure 2), number of fruits per plant, fruit production per plant (Figure 3), fresh fruit weight and fruit dry weight (Figure 4).
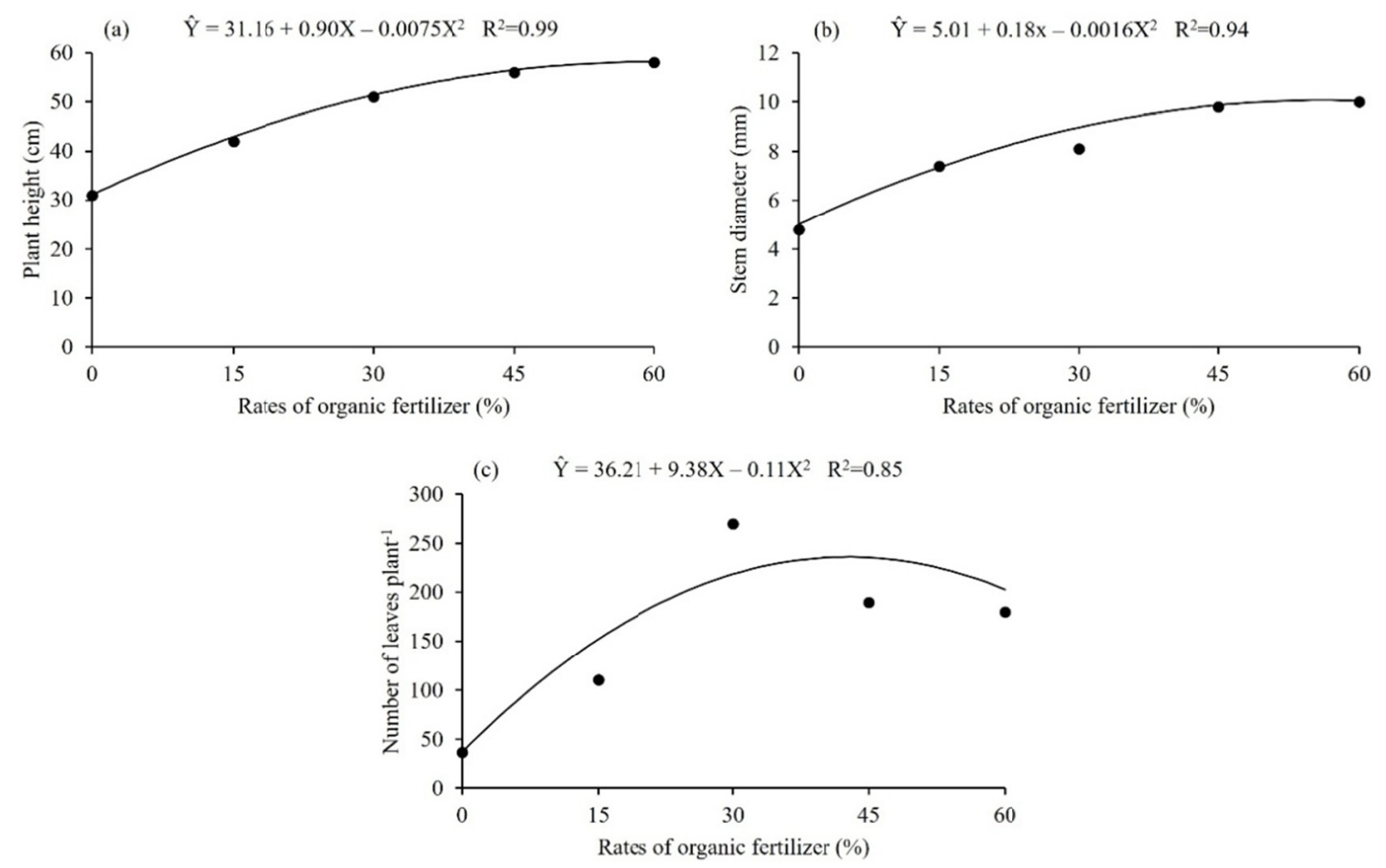

Figure 1. Plant height (a), stem diameter (b), and number of leaves per plant (c) of smell pepper submitted to rates of organic fertilizer in a greenhouse at 103 days after sowing
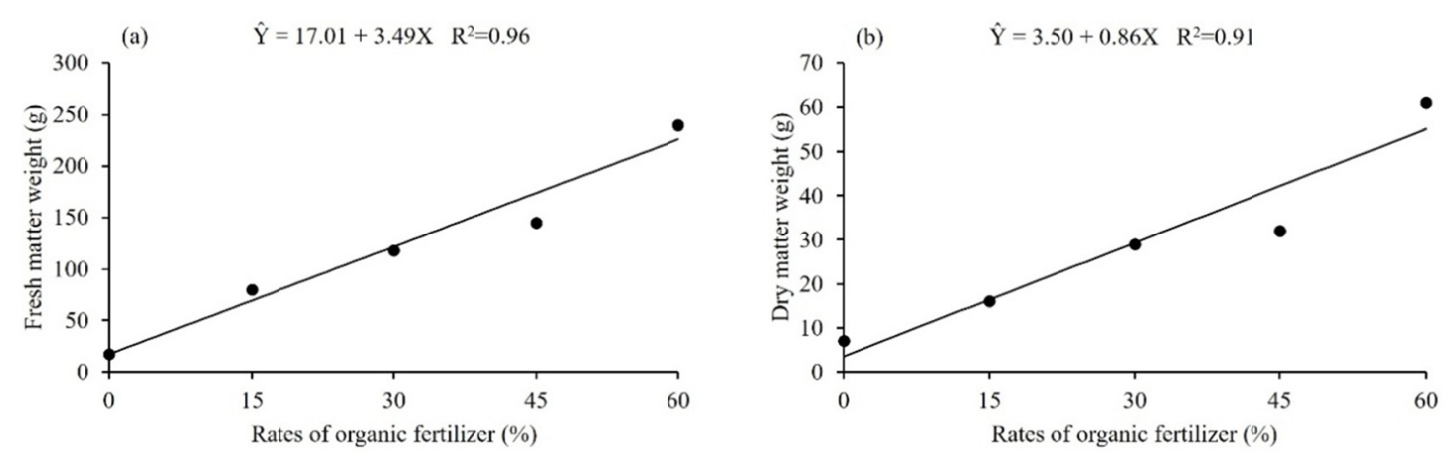

Figure 2. Fresh matter weight (a), and dry matter weight (b) of smell pepper submitted to rates of organic fertilizer in a greenhouse at 103 days after sowing 
(a)

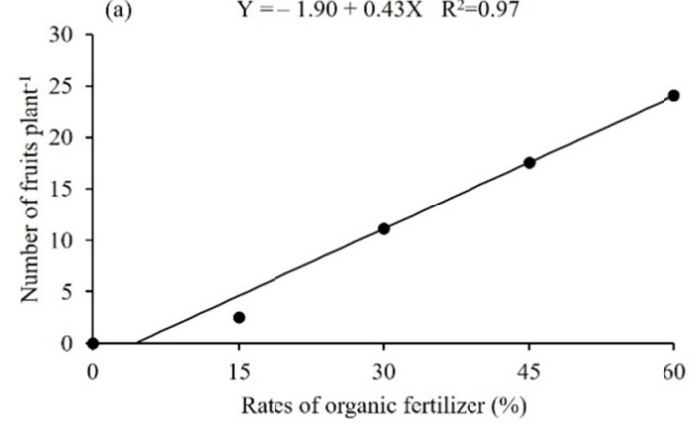

(b)

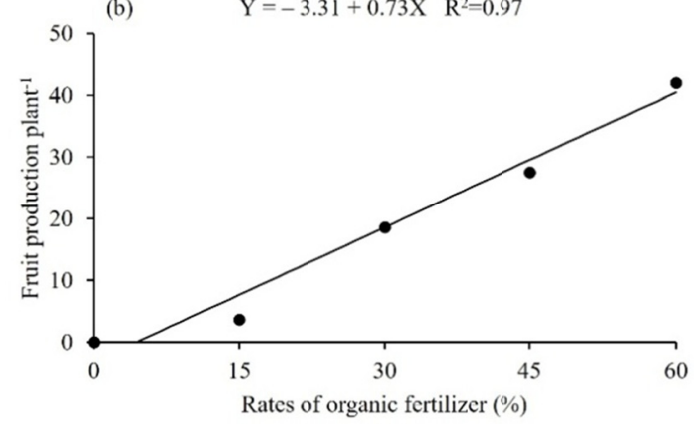

Figure 3. Number (a), and fruit production per plant (b) of smell pepper submitted to rates of organic fertilizer in a greenhouse at 103 days after sowing
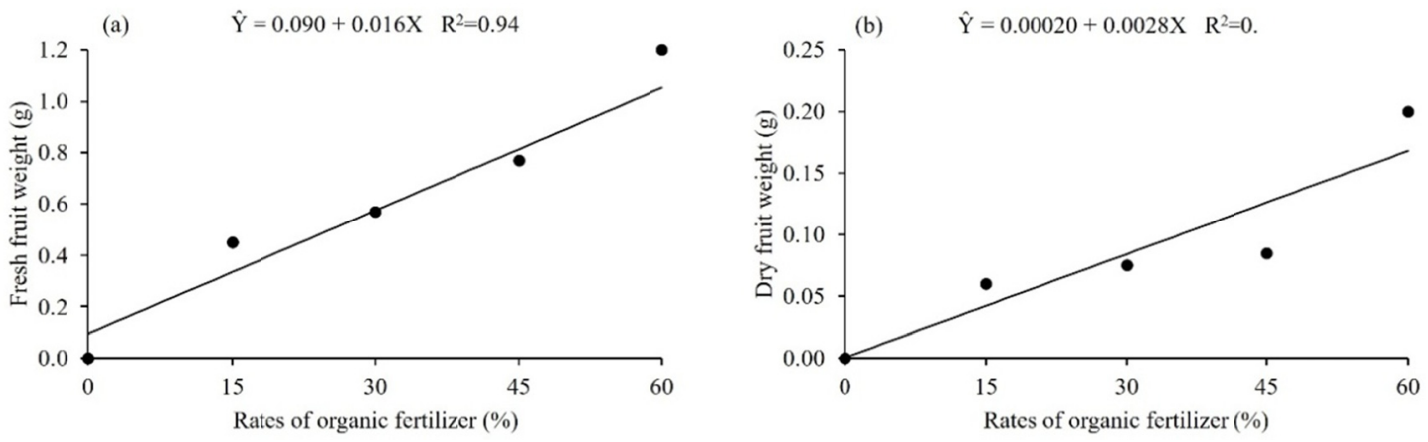

Figure 4. Fresh fruit weight (a), and dry fruit weight (b) of smell pepper submitted to rates of organic fertilizer in a greenhouse at 103 days after sowing

Number of leaves, stem diameter and plant height showed mean values of $163.3 ; 8.1 \mathrm{~mm}$; and $48.1 \mathrm{~cm}$, respectively, with maximum technical efficiency of $9.91 \mathrm{~mm}$, and 228.7 obtained in rates of $55.37 \%$ and $41.05 \%$ of organic fertilizer for stem diameter and number of leaves, respectively. Flores, Almeida, Politi, Prado and Barbosa (2012) cultivating chilli pepper in nutrient solution, observed that at 56 days after transplantation in complete treatment (N, P, K, Ca, Mg, S, B, Cl, Cu, Fe, Mn, Mo, and $\mathrm{Zn}$ ), plants showed a height of $29.2 \mathrm{~cm}$, a stem diameter of $6.1 \mathrm{~mm}$ and a number of leaves of 32, lower compared to the present study.

By results obtained observed proportional increase in weight values of fresh and dry matter of plant, fresh and dry fruit weight, fruit production per plant, and number of fruits per plant, according to increase in rates of organic fertilizer. The effects on cycle and vegetative development of smell pepper observed that application of organic fertilizer at rates of $60 \%$ promoted plants flowering and maturation of fruits early (Figure 5), while plants submitted to control treatment did not produce fruits until moment of harvest (Figure 6). 


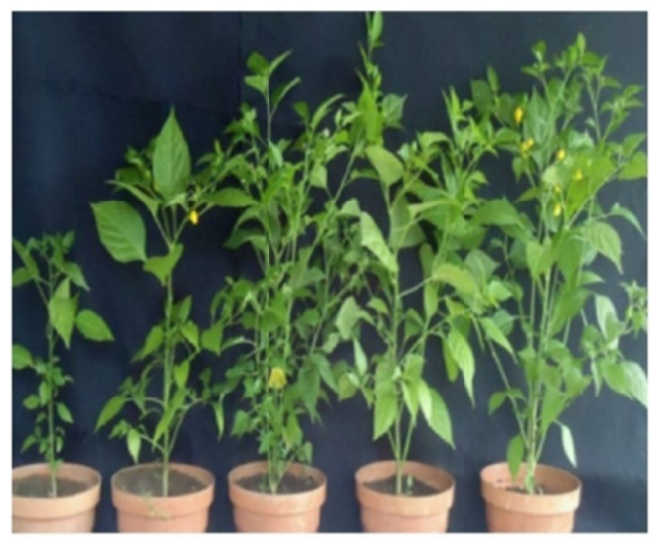

$$
\begin{array}{lllll}
0 \% & 15 \% & 30 \% & 45 \% & 60 \%
\end{array}
$$

Figure 5. Smell pepper with organic fertilizer at rates of $0,15,30,45$, and $60 \%$, in a greenhouse

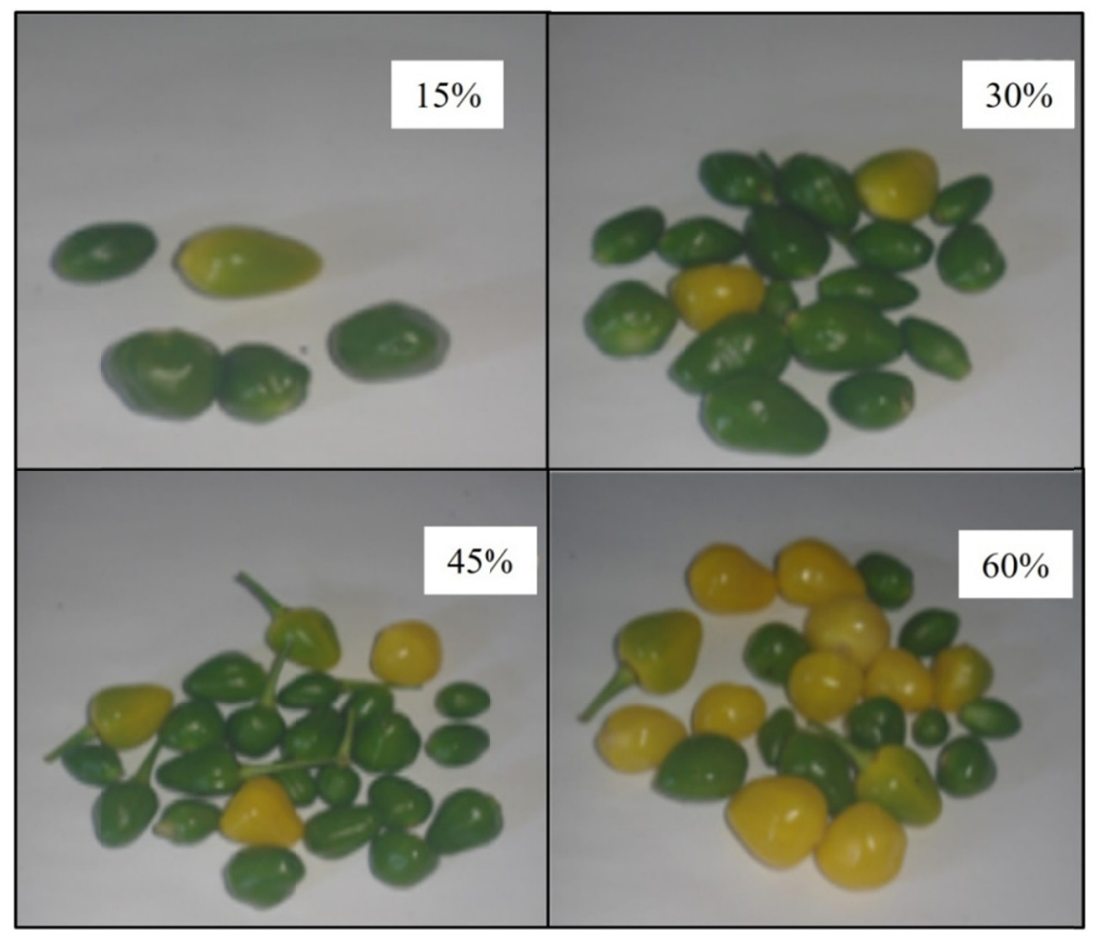

Figure 6. Smell pepper fruits at rates of $15,30,45$, and $60 \%$ of organic fertilizer, harvested at 103 days after sowing

The average values of fresh and dry matter of smell pepper were of $121.74 \mathrm{~g}$, and $29.20 \mathrm{~g}$, respectively, possibly the low values were promoted by shorter planting time, genetic characteristics and/or growing conditions. Malavolta et al. (1991) obtained values of fresh matter of $386 \mathrm{~g} \mathrm{plant}^{-1}$, and dry matter of $119 \mathrm{~g} \mathrm{plant}^{-1}$ in chili pepper.

The mean values of fresh and dry weight of fruits, fruit production per plant, and number of fruits per plant were $0.72 \mathrm{~g}, 0.2 \mathrm{~g}, 23.24 \mathrm{~g}$, and 13.87, respectively. Poltronieri et al. (2006), evaluating cultural management in smell pepper, founded that organic fertilization $\left(1 \mathrm{~kg} \mathrm{plant}^{-1}\right.$ of manure) in combination with pruning and irrigation obtained best results in fruit production $\left(2333.78 \mathrm{~g} \mathrm{plant}^{-1}\right)$.

\subsection{Micronutrient Content in Leaves and Fruits of Smell Pepper}

Micronutrient contents in leaves and fruits of smell pepper showed an adjustment for quadratic equation, with exception of $\mathrm{Fe}, \mathrm{Mn}$, and $\mathrm{Zn}$ contents in leaves that did not show statistical difference (Figure 7). The variations 
in contents occurred due are dependent on nutrient availability in soil (Fernandes, Grohskopf, Gomes, Ferreira, \& Büll, 2015), absorption rate, and interaction with growth rate of plant (Almeida, Cruz, Castro, \& Fagundes, 2014), additionally, considering that nutrients release of organic fertilizer are slow compared to soluble mineral fertilizers (Pereira, Arf, Santos, Oliveira, \& Komuro, 2015), due to mineralization of organic matter, would justify the results obtained in study.

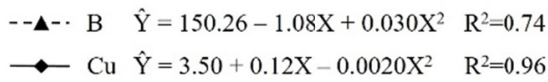

(a)

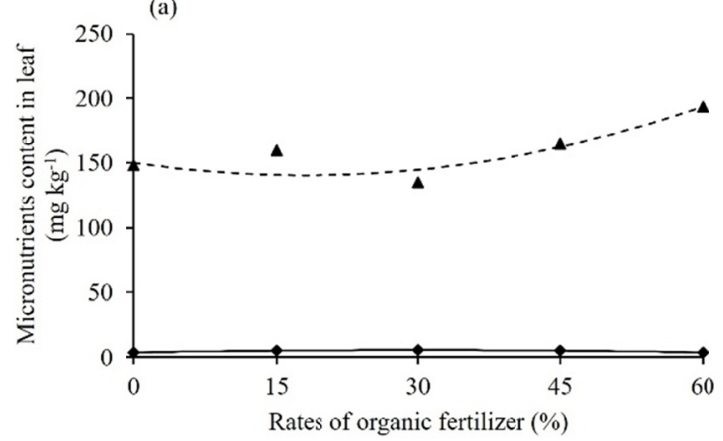

(b)

$\longrightarrow$ Fe $\hat{\mathrm{Y}}=10.59+2.40 \mathrm{X}-0.030 \mathrm{X}^{2} \quad \mathrm{R}^{2}=0.50$

- - A-· B $\quad \hat{\mathrm{Y}}=5.64+2.89 \mathrm{X}-0.043 \mathrm{X}^{2} \quad \mathrm{R}^{2}=0.78$

$\multimap \mathrm{Cu} \quad \hat{\mathrm{Y}}=0.57+038 \mathrm{X}-0.0053 \mathrm{X}^{2} \quad \mathrm{R}^{2}=0.96$

X Mn $\hat{Y}=2.25+1.16 \mathrm{X}-0.015 \mathrm{X}^{2} \quad \mathrm{R}^{2}=0.86$

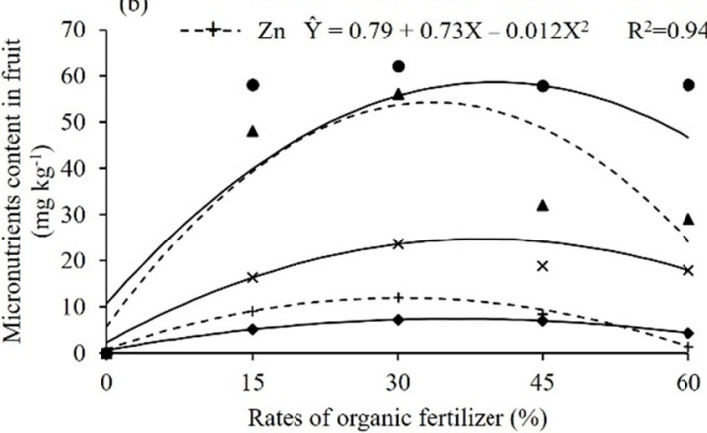

Figure 7. Micronutrient content in leaves (a) and fruits (b) of smell pepper submitted to rates of organic fertilizer in a greenhouse at 103 days after sowing

Smell pepper showed the following order in micronutrients content in leaf tissue: $\mathrm{Fe}>\mathrm{B}>\mathrm{Mn}>\mathrm{Zn}>\mathrm{Cu}$, while in fruits were: $\mathrm{Fe}>\mathrm{B}>\mathrm{Mn}>\mathrm{Zn}>\mathrm{Cu}$. According to Prado et al. (2011), highest requirements of micronutrients for tomatoes, vegetables belonging to same family of peppers, were Fe, Zn, and Mn. Malavolta et al. (1991) verified for the chili pepper the following order of requirement $\mathrm{Fe}>\mathrm{B}>\mathrm{Mn}>\mathrm{Zn}>\mathrm{Cu}$, observing high value of boron.

For most limiting micronutrients $(\mathrm{B}, \mathrm{Zn}$, and $\mathrm{Cu}), \mathrm{B}$ showed highest requirement, with maximum leaf content of $140.53 \mathrm{mg} \mathrm{kg}^{-1}$ obtained at a rate of $18.03 \%$ of organic fertilizer. High boron content in plant was identified by Malavolta et al. (1991) in chili pepper (105.33 mg kg-1 of B), suggesting a higher requirement of boron in plants development of genus Capsicum.

Regarding the boron content in fruits was $39.93 \mathrm{mg} \mathrm{kg}^{-1}$, with estimated maximum content of $53.80 \mathrm{mg} \mathrm{kg}$ obtained in rate of $33.3 \%$ of organic fertilizer. Similar results in fruits were observed by Silva, Boaretto, Fernandes and Scivittaro (2000) in bell pepper (39.7 $\mathrm{mg} \mathrm{kg}^{-1}$ ) and Malavolta et al. (1991) in chili pepper (41.66 $\mathrm{mg} \mathrm{kg}^{-1}$ ).

Boron content was higher in fruits comparatively in leaf, possibly due to its function in plant acting on flowering (Leonel, Araújo \& Tecchio, 2015). By results obtained was observed that bean straw resulted in highest values for boron content $\left(61.8 \mathrm{mg} \mathrm{kg}^{-1}\right)$ compared to other organic waste used in preparation of organic fertilizer.

For the Fe content in leaves was observed a variation of $196 \mathrm{mg} \mathrm{kg}^{-1}$ (control) to $369.57 \mathrm{mg} \mathrm{kg}^{-1}$ (45\% of organic fertilizer). Malavolta et al. (1991) observed Fe content in leaves of chilli pepper equivalent to $113 \mathrm{mg} \mathrm{kg}^{-1}$, and in fruits the estimated maximum level was $58.31 \mathrm{mg} \mathrm{kg}^{-1}$ obtained in rate of $39.8 \%$ of organic fertilizer.

$\mathrm{Cu}$ content in leaf ranged from $3.5 \mathrm{mg} \mathrm{kg}^{-1}$ (control and $60 \%$ of organic fertilizer) to $5.4 \mathrm{mg} \mathrm{kg}^{-1}$ (30\% f organic fertilizer), with maximum estimated content of $5.32 \mathrm{mg} \mathrm{kg}^{-1}$ at rates of $30.2 \%$ of organic fertilizer. While, in fruits content ranged from 4.8 to $7.4 \mathrm{mg} \mathrm{kg}^{-1}$, with maximum content of $7.29 \mathrm{mg} \mathrm{kg}^{-1}$ obtained in rate of $35.61 \%$ of organic fertilizer, verifying a higher capacity of $\mathrm{Cu}$ absorption by fruits. Silva et al. (2000) observed in chili pepper fruits that $\mathrm{Cu}$ content varying from 2.3 to $3.0 \mathrm{mg} \mathrm{kg}$, showing continuous absorption by fruits, due to translocation of nutrient to other parts of plant, reinforcing the results obtained in present study.

$\mathrm{Mn}$ and $\mathrm{Zn}$ leaf contents varied from $48.82 \mathrm{mg} \mathrm{kg}^{-1}$ (control) to $62.2 \mathrm{mg} \mathrm{kg}^{-1}$ (45\% of organic fertilizer) and $16.72 \mathrm{mg} \mathrm{kg}^{-1}$ (15\% of organic fertilizer) to $33.72 \mathrm{mg} \mathrm{kg}^{-1}$ (30\% of organic fertilizer), respectively. In fruits, maximum contentes of $\mathrm{Mn}$ and $\mathrm{Zn}$ were $24.16 \mathrm{mg} \mathrm{kg}^{-1}$ and $12.11 \mathrm{mg} \mathrm{kg}^{-1}$ in rates of $37.72 \%$ and $31.25 \%$ of 
organic fertilizer, respectively. Malavolta et al. (1991) observed in chili pepper values of 53 and $20 \mathrm{mg} \mathrm{kg}^{-1}$ for $\mathrm{Mn}$ and Zn, respectively.

By results obtained were observed that most demanding micronutrients for smell pepper were $\mathrm{Fe}$, and $\mathrm{B}$, followed by $\mathrm{Mn}, \mathrm{Zn}, \mathrm{Cu}$, and Mo, similar to described by Malavolta et al. (1991) in chili pepper. However, the values obtained, with exception of boron, are below those considered adequate by Malavolta (2006) for tomato, in which belongs the same family of smell pepper, additionally, is important to emphasize that plants did not show symptoms of deficiency in leaves.

Micronutrient contents in fruits were lower compared to leaves, with exception of $\mathrm{Cu}$ that obtained higher value in fruits, similar to described by Marcussi and Villas Bôas (2003) in bell pepper. The nutrients contained in leaves are important in yield, due micronutrients with mobility in phloem can be retranslocated from mature leaves to preferential vegetative organs, such as young leaves, flowers, and fruits (Marschner, 2012).

\subsection{Micronutrients Accumulation in Leaves and Fruits of Smell Pepper}

Micronutrient accumulation in leaves showed the following decreasing order $\mathrm{Fe}>\mathrm{B}>\mathrm{Mn}>\mathrm{Zn}>\mathrm{Cu}$ (Figure 8), with mean values of $1472.56 ; 821.16 ; 289.48 ; 131.90$; and $22.65 \mu \mathrm{g}$ leaves ${ }^{-1}$, respectively. Similar results were observed by Silva et al. (2000) and Malavolta et al. (1991) in which nutrients with greatest accumulation by bell pepper and chili pepper were $\mathrm{Fe}, \mathrm{B}, \mathrm{Mn}$, and $\mathrm{Cu}$.
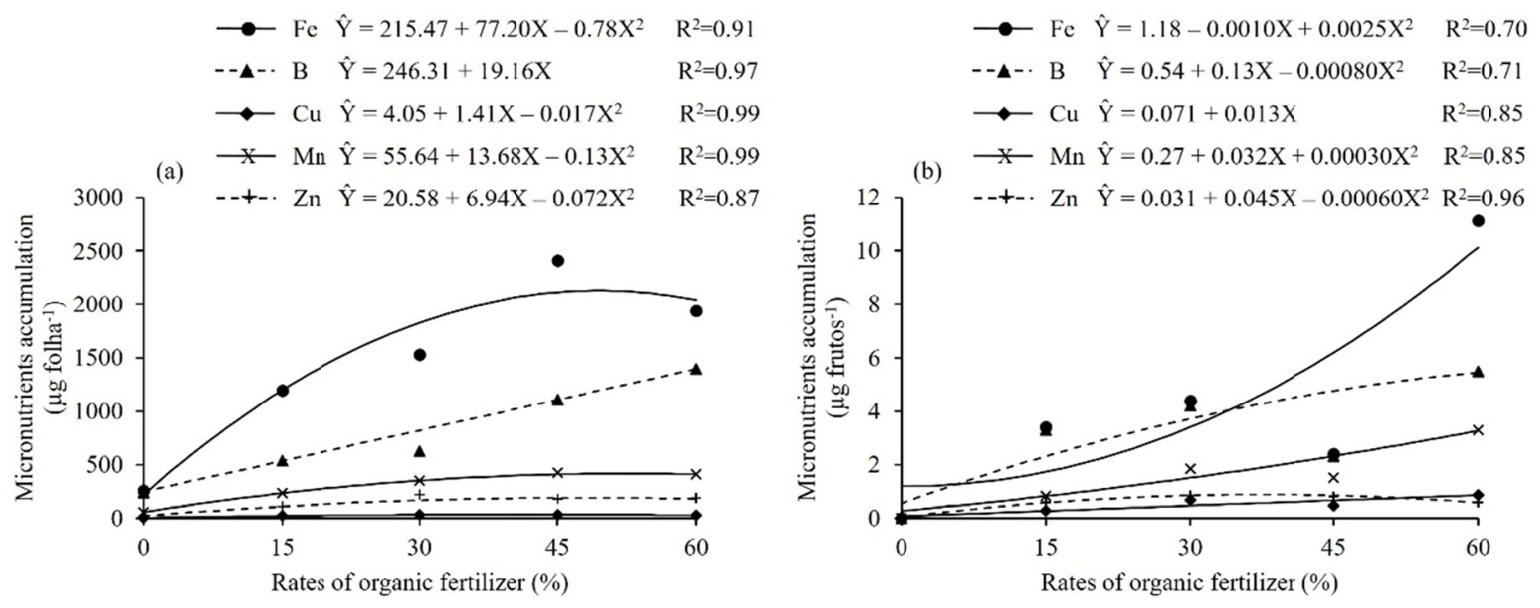

Figure 8. Micronutrient accumulation in leaves (a) and fruits (b) of smell pepper submitted to rates of organic fertilizer in a greenhouse at 103 days after sowing

The maximum accumulation estimated in leaves for $\mathrm{Fe}, \mathrm{Mn}, \mathrm{Zn}$, and $\mathrm{Cu}$ of $2115.1 ; 413.25 ; 188,317$; and 32.39 $\mu \mathrm{g}$ leaves ${ }^{-1}$ were obtained at rates of $49.21 \% ; 52.26 \% ; 48.33 \%$; and $40.25 \%$ of organic fertilizer, respectively.

In fruits the micronutrient accumulation showed a similar tendency to absorption in leaves (Figure 8), with best fit for quadratic equation, only $\mathrm{Cu}$ that had best fit for linear equation, in which was verified that average values obtained were of $4.52 ; 3.22 ; 1.66 ; 0.56$; and $0.47 \mu \mathrm{g}$ fruits $^{-1}$ for $\mathrm{Fe}, \mathrm{B}, \mathrm{Mn}, \mathrm{Zn}$, and $\mathrm{Cu}$, respectively.

\subsection{Export of Micronutrients by Smell Peppers Fruits}

Micronutrient contents in chili pepper fruits showed a better fit for quadratic models, with exception of $\mathrm{Fe}$ that did not presented statistical difference. Micronutrient exportation were B $\left(57.54 \mathrm{~g} \mathrm{ha}^{-1}\right), \mathrm{Fe}\left(74.73 \mathrm{~g} \mathrm{ha}^{-1}\right), \mathrm{Cu}$ $\left(8.14 \mathrm{~g} \mathrm{ha}^{-1}\right), \mathrm{Mn}\left(28.08 \mathrm{~g} \mathrm{ha}^{-1}\right), \mathrm{Zn}\left(10.85 \mathrm{~g} \mathrm{ha}^{-1}\right)$ (Figure 9), and nutrient extraction by fruits smell pepper in descending order was $\mathrm{Fe}>\mathrm{B}>\mathrm{Mn}>\mathrm{Zn}>\mathrm{Cu}$. 


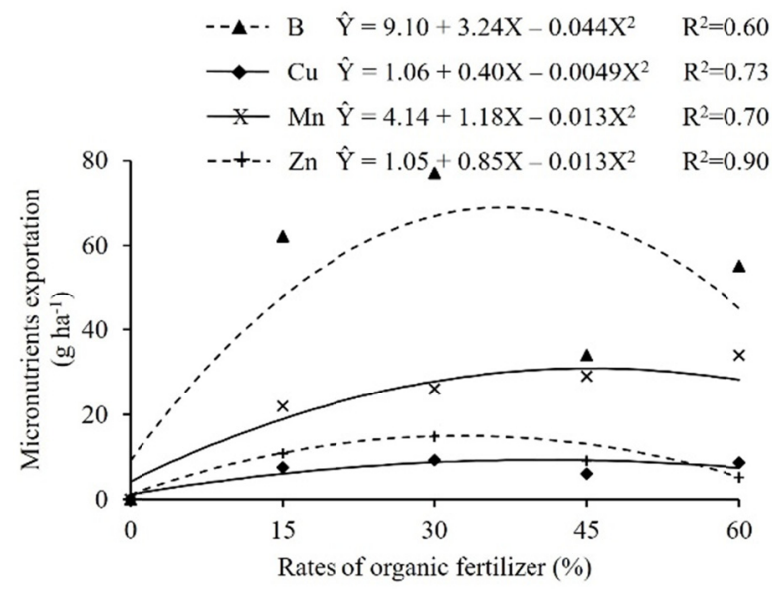

Figure 9. Micronutrients exportation in smell pepper fruits submitted to rates of organic fertilizer in a greenhouse at 103 days after sowing

The exported quantities of micronutrients per tonne of chilli pepper fruits shown in Table 2, allowed to identify that at rate of $60 \%$ of organic fertilizer promoted the highest export of micronutrients by fruits.

Table 2. Exported quantity of $\mathrm{Fe}, \mathrm{B}, \mathrm{Mn}, \mathrm{Zn}$, and $\mathrm{Cu}$ per ton of smell pepper fruits submitted to rates of organic fertilizer

\begin{tabular}{|c|c|c|c|c|c|}
\hline Rates of organic fertilizer & $\mathrm{Fe}$ & $\mathrm{B}$ & $\mathrm{Mn}$ & $\mathrm{Zn}$ & $\mathrm{Cu}$ \\
\hline$\%$ & ------ & 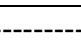 & ---- g & 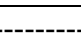 & ---- \\
\hline $0 *$ & - & - & - & - & - \\
\hline 15 & 7.47 & 6.23 & 2.65 & 1.27 & 0.78 \\
\hline 30 & 8.24 & 7.67 & 3.02 & 1.52 & 0.95 \\
\hline 45 & 3.32 & 3.57 & 2.12 & 0.98 & 0.62 \\
\hline 60 & 10.85 & 5.53 & 3.42 & 0.55 & 0.88 \\
\hline Average & 7.47 & 5.75 & 2.80 & 1.08 & 0.81 \\
\hline
\end{tabular}

Note. * There was no fruit production in treatment

The quantities of micronutrients exported by fruit represent an important component of soil nutrient losses, in which should be refunded, considering that if these exported quantities of micronutrients are not supplied to crop after each harvest, the tendency is that over time, the smell pepper will show symptoms of nutritional deficiency, especially in high yield and in soils of low fertility, characteristic of Amazon soil (Vale Júnior, Souza, Nascimento, \& Cruz, 2011). While, the micronutrients contained in aerial part can be incorporated into soil, if there is a program of reuse of cultural residues.

\section{Conclusions}

Fertilization at rate of $60 \%$ of organic fertilizer is not enough to result in maximum production of smell pepper fruit, suggesting the need to conduct future research from rate of $60 \%$ of organic fertilizer.

The content and accumulation of micronutrients in smell pepper leaves show the following decreasing order $\mathrm{Fe}>$ $\mathrm{B}>\mathrm{Mn}>\mathrm{Zn}>\mathrm{Cu}$, and $\mathrm{Fe}>\mathrm{B}>\mathrm{Mn}>\mathrm{Zn}>\mathrm{Cu}$, respectively.

Smell peppers show the following order of absorption in content, accumulation, and export of micronutrients: $\mathrm{Fe}>\mathrm{B}>\mathrm{Mn}>\mathrm{Zn}>\mathrm{Cu}$.

\section{References}

Alhrout, H. H. (2017). Response of growth and yield components of sweet pepper to tow different kinds of fertilizers under green house conditions in Jordan. Journal of Agricultural Sciences, 9, 265-272. https://doi.org/10.5539/jas.v9n10p265 
Almeida, M. O., Cruz, M. C., Castro, G. D. M., \& Fagundes, M. C. P. (2014). Growth and nutrient uptake by yellow passion fruit seedlings produced in organic and commercial substrates and nitrogen fertilization. Revista Brasileira de Ciências Agrárias, 9, 180-185. https://doi.org/10.5039/agraria.v9i2a3593

Costa, A. R. S., Ximenes, T. C. F., Ximenes, A. F., \& Beltrame, L. T. C. (2015). The processo f composting and its potential in the recycling of organic waste. Revista GEAMA, 1, 246-260.

Domenico, C. I., Coutinho, J. P., Godoy, H. T., \& Melo, A. M. T. (2012). Agronomic traits and pungency of chilli pepper. Horticultura Brasileira, 30, 466-472. https://doi.org/10.1590/S0102-05362012000300018

Donagema, G. K., Campos, D. V. B., Calderano, S. B., Teixeira, W. G., \& Viana, J. H. M. (2011). Manual de métodos de análise de solos (2nd ed.). Rio de Janeiro: Embrapa Solos.

Embrapa. (2013). Sistema brasileiro de classificação de solos (3rd ed.). Brasília: Embrapa.

Fernandes, D. M., Grohskopf, M. A., Gomes, E. R. G., Ferreira, N. R., \& Büll, L. T. (2015). Phosphorus in soil solution in response to the application of mineral and organomineral fluid fertilizers. Irriga, 1, 14-27. https://doi.org/10.15809/irriga.2015v1n1p14

Flores, R. A., Almeida, T. B. F., Politi, L. S., Prado, R. M., \& Barbosa, J. C. (2012). Growth and nutritional disorder in chili pepper grown in nutrient solutions with macronutrient omission. Revista Brasileira de Ciências Agrárias, 7, 104-110. https://doi.org/10.5039/agraria.v7i1a1648

Fonseca, R. M., Lopes, R., Willian, S. B., Lopes, M. T. G., \& Ferreira. F. M. (2008). Morphologic characterization and genetic diversity of Capsicum chinense Jacq. accessions along the upper Rio Negro Amazonas. Crop Breeding and Applied Biotechnology, 8, 187-194. https://doi.org/10.12702/1984-7033. v08n03a02

Laviola, B. G., \& Dias, L. A. (2008). Nutrient concentration in Jatropha curcas L. leaves and fruits and estimated extraction at harvest. Revista Brasileira de Ciencia do Solo, 32, 1969-1975. https://doi.org/10.1590/S0100- 06832008000500018

Leonel, S., Araújo, J. F., \& Tecchio, M. A. (2015). Bio and organomineral fertilization: Nutrient concentrations in the leaf and yield of sugar apple fruits. Irriga, 1, 40-51. https://doi.org/10.15809/irriga.2015v1n1p40

Malavolta, E. (2006). Manual de nutrição de plantas. São Paulo: Agronómica Ceres.

Malavolta, E., Malavolta, M. L., Cabral, C. P., \& Carvalho, M. J. R. (1991). Nota sobre as exigências nutricionais da pimenta malagueta (Capsicum frutescens). Revista de Agricultura, 66, 193-201.

Marcussi, F. F. N., \& Villas Bôas, R. L. (2003). Micronutrient concentration in the bell pepper plant development under fertirrigation. Irriga, 8, 120-131.

Marschner, H. (2012). Mineral nutrition of higher plants (3rd ed.). London: Elsevier. https://doi.org/10.1016/ B978-0-12-384905-2.00015-7

Oliveira, J. R., Gomes, R. L. F., Araújo, A. S. F., Marini, F. S., Lopes, J. B., \& Araújo, R. M. (2014). Nutritional status and yield of pepper with the use of liquid biofertilizers. Revista Brasileira de Engenharia Agrícola e Ambiental, 18, 1241-1246. https://doi.org/10.1590/1807-1929/agriambi.v18n12p1241-1246

Oliveira, R. F., Teixeira, B. L., \& Germano, V. L. C. (2004). Composto orgânico de lixo e adubos orgânicos tradicionais na produção de matéria seca de milho e na fertilidade do solo. Belém: Embrapa.

Paula, J. A. M., Reis, J. B., Ferreira, L. H. M., Menezes, A. C. S., \& Paula, J. R. (2010). Pimenta genus: botanical aspects, chemical composition and pharmacological potential. Revista Brasileira de Plantas Medicinais, 12, 363-379. https://doi.org/10.1590/S1516-05722010000300015

Pereira, L. B., Arf, O., Santos, N. C. B., Oliveira, A. E. Z., \& Komuro, L. K. (2015). Fertilization management in bean crop under organic production system. Pesquisa Agropecuária Tropical, 45, 29-38. https://doi.org/ $10.1590 / 1983-40632015 \mathrm{v} 4528018$

Pimentel, M. S., De-Polli, H., \& Lana, A. M. Q. (2009). Soil chemical attributes using organic compost in lettuce-carrot intercropping. Pesquisa Agropecuária Tropical, 39, 225-232.

Pinto, C. M. F., Lima, P. C., Salgado, L. T., \& Caliman, F. R. B. (2006). Nutrição mineral e adubação para pimenta. Informe Agropecuário, 27, 50-57.

Poltronieri, M. C., Botelho, S. M., Lemos, O. F., Albuquerque, A. S., Silva Júnior, A. C., \& Palhares, T. C. (2006). Tratos culturais em pimenta de cheiro (Capsicum chinense jacquin). Belém: Embrapa. 
Prado, R. M., Santos, V. H. G., Gondim, A. R. O., Alves, A. U., Filho. A. B. C., \& Correia, M. A. R. (2011). Growth and nutrient absorption by Raisa tomato cultivar grown in hydroponic system. Semina: Ciências Agrárias, 32, 19-30. https://doi.org/10.5433/1679-0359.2011v32n1p19

Reifschneider, F. J. B. (2000). Capsicum: Pimentas e pimentões no Brasil. Brasília: Embrapa.

Sá, F. V. S., Souto, L. S., Paiva, E. P., Araújo, E. B. G., Oliveira, F. A., Mesquita, E. F., Ferreira Neto, M., \& Dantas, J. S. (2017). Initial development and tolerance of bell pepper (Capsicum annuum) cultivars under salt stress. Journal of Agricultural Science, 9, 181-189. https://doi.org/10.5539/jas.v9n11p181

Silva, F. A. S., \& Azevedo, C. A. V. (2016). The Assistat Software Version 7.7 and Its Use in the Analysis of Experimental Data. African Journal of Agricultural Research, 11, 3733-3740. https://doi.org/10.5897/ AJAR2016.11522

Silva, M. A. G., Boaretto, A. E., Fernandes, H. G., \& Scivittaro, W. B. (2000). Exigência de micronutrientes por plantas de pimentão cultivadas em ambiente protegido. Acta Scientiarum. Agronomy, 22, 1107-1113.

Vale Júnior, J. F., Souza, M. I. L., Nascimento, P. P. R. R., \& Cruz, D. L. S. (2011). Soils of the Amazon: Etnopedology and sustainable development.RevistaAgro@mbiente On-line, 5, 158-165.

Viégas, I. J. M., Sousa, G. O., Silva, A. F., Carvalho, J. G., \& Lima, M. M. (2013). Mineral composition and visual symptoms of nutrients deficiencies in long pepper plants (Piper hispidinervum C. DC.). Acta Amazonica, 43, 43-50. https://doi.org/10.1590/S0044-59672013000100006

Zhu, N. (2007). Effect of low initial $\mathrm{C} / \mathrm{N}$ ratio on aerobic composting of swine manure with rice straw. Bioresource Technology, 98, 9-13. https://doi.org/10.1016/j.biortech.2005.12.003

\section{Copyrights}

Copyright for this article is retained by the author(s), with first publication rights granted to the journal.

This is an open-access article distributed under the terms and conditions of the Creative Commons Attribution license (http://creativecommons.org/licenses/by/4.0/). 